\title{
Effects of Quercetin Administration on the Pregnancy Outcome of Diabetic Rats
}

\author{
Camila Pereira Braga ${ }^{1 *}$, Rafaela de Fátima Ferreira Baptista ${ }^{2}$, Fernando Barbosa Peixoto ${ }^{1}$, Ana Carolina Momentti ${ }^{1}$, Fábio Henrique Fava ${ }^{1}$ \\ and Ana Angélica Henrique Fernandes ${ }^{1}$
}

${ }^{1}$ Departamento de Química e Bioquímica, Instituto de Biociências - Campus de Botucatu - Universidade Estadual Paulista "Júlio de Mesquita Filho" - UNESP - Brazil ${ }^{2}$ Departamento de Farmacologia, Instituto de Biociências - Campus de Botucatu Universidade Estadual Paulista "Júlio de Mesquita Filho" - UNESP - Brazil

\begin{abstract}
Objective: Investigate the effects of diabetes and treatment with quercetin on the maternal reproductive performance and impact on foetal growth

Study design: A total of 32 female Wistar rats were distributed into four groups: non-diabetic (G1); non-diabetic treated with quercetin (G2); diabetic (G3) and diabetic treated with quercetin (G4). At day 21 of pregnancy, each rat was anesthetized and humanely killed for laparotomy; was observed reproductive performance, foetal and placental weights and the placental index. Maternal and foetal data were analysed by ANOVA followed by the Tukey test. Foetal weight classification was assessed by Goodman's test.
\end{abstract}

Results: Diabetes and diabetes treated with quercetin caused placentomegaly an increased placental index and small foetus rates for pregnancy age.

Conclusion: Quercetin, administered to pregnant diabetic rats, controlled glucose levels and promoted weight gain compared to untreated diabetic rats, but it did not improve reproductive performance or foetal or placental development.

Keywords: Diabetes mellitus; Foetus; Placenta; Pregnancy; Quercetin

\section{Introduction}

Diabetes mellitus is a syndrome characterized by an absolute or relative deficiency of the action of insulin in target organs, resulting in the exposure of all tissues to chronic hyperglycaemia [1]. This deficiency in insulin action, which is the common basis of diabetes, causes characteristic abnormalities in the metabolism of lipids, proteins and carbohydrates, resulting in high concentrations of glucose in the blood, featuring hyperglycaemia with metabolic disorders [2].

Streptozotocin (STZ), an antibiotic produced by Streptomyces achromogenes, is a frequently used agent in experimental diabetes. In STZ-induced type 1 diabetes, hyperglycaemia and oxidative stress have been implicated in the aetiology and pathology of disease complications [3]. The mechanism by which STZ destroys cells of the pancreas and induces hyperglycaemia is still unclear. One of the actions that have been attributed to STZ is the depletion of intracellular nicotinamide dinucleotide (NAD) in islet cells. In addition, STZ has been shown to induce DNA strand breaks and methylation in pancreatic islet cells. Chemicals with antioxidant properties and free radical scavengers were shown to prevent pancreatic islets against the cytotoxic effects of STZ or alloxan, another agent that induces experimental diabetes [4] because inhibit the formation of free radicals: in the initiation (by interacting with superoxide ions), the formation of hydroxyl radicals (by chelating iron ions) and lipid peroxidation (by reacting with lipid peroxyl radicals) [5].

Flavonoids are a group of naturally occurring compounds widely distributed as secondary metabolites throughout the plant kingdom. They have been recognized for having interesting clinical properties, such as anti-inflammatory, antiallergic, antiviral, antibacterial, and antitumoural activities [6].

One of these flavonoids, quercetin (3,5,7,3,4-pentahydroxyflavone), prevents oxidant injury and cell death via several mechanisms, such as scavenging oxygen radicals $[7,8]$ protecting against lipid peroxidation [9] and chelating metal ions [10]. Quercetin is capable of inhibiting biomolecule oxidation and it can alter antioxidant defence pathways in vivo and in vitro [11]. Quercetin is present in many plants, such as Camellia sinensis, Allium sativum, Capsicum frutescens, Ginkga biloba and Hypercium perforatum, which are used for the treatment of diabetes [12]. Quercetin often comprises a major component of the medicinal activity of these plants and it has been shown in experimental studies to have numerous protective effects on the body [12].

Pregnancy complicated by poorly controlled diabetes is associated with an increased risk of abortion, congenital malformations and perinatal mortality [13]. Diabetes mellitus is a state of chronic hyperglycaemia and a major cause of serious micro and macrovascular diseases, affecting, therefore, nearly every system in the body. Growing evidence indicates that oxidative stress is increased in diabetes due to the overproduction of reactive oxygen species and the decreased efficiency of antioxidant defences, a process that starts very early and becomes worse over the course of the disease [14].

The aim of the present study was to investigate the effects of diabetes and treatment with quercetin on the maternal reproductive performance and foetal and placental development of rats.

*Corresponding author: Camila Pereira Braga, Departamento de Química e Bioquímica - Instituto de Biociências - UNESP, Rubião Júnior - Zip code: 18618-970 Botucatu, São Paulo, Brazil, Tel: + 55 (14) 3811-6255, + 55 (14) 8815-4282; Email: braga_ca@ibb.unesp.br, braga_ca@yahoo.com.br

Received December 15, 2011; Accepted January 11, 2012; Published January 16,2012

Citation: Braga CP, de Fátima Ferreira Baptista R, Peixoto FB, Momentti AC, Fava $\mathrm{FH}$, et al (2012) Effects of Quercetin Administration on the Pregnancy Outcome of Diabetic Rats. J Diabetes Metab 3:180. doi:10.4172/2155-6156.1000180

Copyright: ( 2012 Braga CP, et al. This is an open-access article distributed unde the terms of the Creative Commons Attribution License, which permits unrestricted use, distribution, and reproduction in any medium, provided the original author and source are credited. 
Citation: Braga CP, de Fátima Ferreira Baptista R, Peixoto FB, Momentti AC, Fava FH, et al. (2012) Effects of Quercetin Administration on the Pregnancy Outcome of Diabetic Rats. J Diabetes Metab 3:180. doi:10.4172/2155-6156.1000180

\section{Materials and Methods}

\section{Animals and experimental groups}

Six-week-old female and male Wistar rats, weighing approximately $190 \mathrm{~g}$ and $220 \mathrm{~g}$, respectively, were obtained from São Paulo State University (UNESP) at Botucatu, São Paulo State, Brazil. During the 3-week acclimatization period and the experimental exposure periods, the rats (four per cage) were maintained in an experimental room under controlled conditions of temperature $\left(22 \pm 2{ }^{\circ} \mathrm{C}\right)$ and humidity (50 $\pm 10 \%)$, with a 12-hour light/dark cycle and ad libitum access to a commercial diet (Purina Rat Chow, Purina, Brazil) and tap water. A total of 32 rats were randomly distributed into four groups ( $n=8$ each): $\mathrm{G} 1=$ non-diabetic, $\mathrm{G} 2=$ non-diabetic treated with quercetin, G3= diabetic and G4= diabetic treated with quercetin. The Experimental Ethical Committee for Animal Research of the Botucatu School / UNESP approved the protocols used in this study.

\section{Induction of diabetes}

The diabetic state was only induced in female rats, by streptozotocin (Sigma Chemical Company, St. Louis, Millstone, United States). Streptozotocin was dissolved in a citrate buffer $(0.1 \mathrm{~mol} / \mathrm{l}, \mathrm{pH} 6.5)$ and administered by intravenous (i.v.) injection at a dose of $60 \mathrm{mg} /$ $\mathrm{kg}$ bodyweight. The diabetic state was confirmed by a blood glucose concentration test of $>220 \mathrm{mg} / \mathrm{dL}$ [15], and the rats were then subjected to mating. To verify pregnancy, vaginal washing was performed where the tip of an automatic pipette containing $10 \mu \mathrm{l}$ of $0.9 \%$ saline was introduced into the vagina of each female and then aspirated. Factors indicative of pregnancy, such as the presence of sperm, were used to define gestational day zero (GD 0) [16].

\section{Administration of quercetin}

With the establishment of pregnancy, quercetin was administered via intragastric gavage. Animals belonging to groups G2 and G4 received the flavonoid quercetin (Q SIGMA.-0125) at a concentration of $50 \mathrm{mg} / \mathrm{kg}$ body weight. The pregnant rats received the flavonoid throughout pregnancy, at intervals of 7 days (the following days of pregnancy: $0,7,14$ and 20). The dose and administration interval of quercetina was based on the protocol adopted in our laboratory [17], which found that quercetina administered at intervals of 7 days can have beneficial effects on biochemical parameters of diabetic rats.

\section{Evaluation of the pregnancy at term}

At day 20 of pregnancy, the dams were weighed to determine body weight gain (maternal weight at day 20 compared to day 0 of pregnancy) and anaesthetized with sodium pentobarbital (Hypnol $3 \%$ ) for laparotomy. The uterus was removed and weighed, and the ovaries and uterine contents were examined to determine the number of corpora lutea and implantation sites, resorptions (embryonic death), and the number and position of viable or dead foetuses. The rate of embryonic loss before implantation was calculated as: (number of corpora lutea - number of implantations) $\times 100 /$ number of corpora lutea, and used as a measure of failed conceptions or pre-implantation losses. The percentage embryonic loss after implantation was calculated as: (number of implantations - number of live foetuses) $\times 100 /$ number of implantations, which was used as a measure of the abortifacient effect or to identify post-implantation loss [18].

Immediately after exploratory laparotomy, all viable foetuses and placentas were weighed to determine the placental index (placental weight/foetal weight). The foetuses were classified by mean \pm SD according to the mean values of foetal weights of the non-diabetic group (G1): as small for pregnancy age (SPA) when the weight was lower than G1 mean - 1.7 SD; appropriate for pregnancy age (APA) when the weight was included in G1 mean $\pm 1.7 \mathrm{SD}$; and large for pregnancy age (LPA) when weight was greater than G1 mean + 1.7 SD [19].

\section{Measurement of glycaemia}

Biochemical parameter were measured using spectrophotometric methods with commercial enzymatic kits (CELM - Modern Laboratory Equipment Company, São Paulo, Brazil).

\section{Statistical analysis}

The results were reported as mean $\pm \mathrm{SD}$. All data were statistically analysed using analysis of variance (ANOVA) followed by the Tukey test. Goodman's test was used for foetal weight classification. Statistical significance was considered as $\mathrm{p}<0.05[20]$.

\section{Results}

In non-diabetic rats (G1) and non-diabetic rats treated with quercetin (G2), normoglycaemia was confirmed with mean glucose values around $110 \mathrm{mg} / \mathrm{dL}$, whereas in diabetic rats (G3) hyperglycaemia was confirmed by mean glucose concentrations of around $309 \mathrm{mg} / \mathrm{dL}$ and diabetic rats treated with quercetina mean glucose concentrations of around $164 \mathrm{mg} / \mathrm{dL}$. A comparison between the diabetic rats (G3) and diabetic rats treated with quercetin (G4) showed that the maternal serum glucose in the group of treated diabetic rats significantly declined $(\mathrm{p}<0.05)$ (Table 1)

Table 1 presents the maternal reproductive performance. The mean number of corporea lutea of G3 and G4 group was not different to any of the other groups. Diabetes (G3) and diabetes treated with quercetin (G4) did not cause a significant decrease in implantation numbers in relation to groups G1 and G2; or live foetus numbers. In relation to maternal weight gain, G1 and G2 showed higher values of weight gain that were not significantly different to each other $(\mathrm{p}>0.05)$, whereas they were significantly different to G3 and G4. The diabetic

\begin{tabular}{|c|c|c|c|}
\hline \multicolumn{2}{|c|}{ G1 } & G2 & G3 \\
\hline Glucose mg/dL & $110.93 \pm 21.58 a$ & $110.69 \pm 9.8 \mathrm{a}$ & $309.2 \pm 56.26 \mathrm{c}$ \\
\hline Maternal weight gain (g) & $127.11 \pm 12.82 \mathrm{c}$ & $137.57 \pm 15.77 \mathrm{c}$ & $63.84 \pm 27.07 \mathrm{a}$ \\
\hline Number of corpora lutea & $11.63 \pm 2.33 \mathrm{a}$ & $12.13 \pm 1.95 \mathrm{a}$ & $9.88 \pm 0.83 \mathrm{a}$ \\
\hline Number of implantation sites & $11.25 \pm 2.31 \mathrm{a}$ & $11.75 \pm 2.18 \mathrm{a}$ & $9.43 \pm 1.51 \mathrm{a}$ \\
\hline Number of live foetuses & $11.13 \pm 2.64 \mathrm{a}$ & $11.63 \pm 1.76 \mathrm{a}$ & $8.88 \pm 1.25 \mathrm{a}$ \\
\hline Pre-implantation loss (\%) & $3.24 \mathrm{a}$ & $3.39 \mathrm{a}$ & $10.63 \pm 1.92 \mathrm{a}$ \\
\hline Post-implantation loss (\%) & $1.64 \mathrm{a}$ & $0.41 \mathrm{a}$ & $4.17 \mathrm{a}$ \\
\hline
\end{tabular}

Mean \pm SD. All data were statistically analysed using analysis of variance (ANOVA) followed by the Tukey test. Means followed by different letters indicate significant differences between the groups $(p<0.05)$. $G 1=$ non-diabetic, $G 2=$ non-diabetic treated with quercetin, $G 3=$ diabetic and $G 4=$ diabetic treated with quercetin .

Table 1: Maternal reproductive performance of the different experimental groups. 
group treated with quercetin showed a higher weight gain compared to the untreated diabetic group, but it did not equal the values observed for the control groups. Not significant increase $(p>0.05)$ in the rate of pre-implantation loss was observed in relation to the groups (G1, G2, G3 and G4), and the rate of post-implantation was significantly different between the control groups (G1 and G2) and the diabetic groups (G3 and G4).

Table 2 shows that the foetal weights were significantly lower in G3 and G4 compared to G1 and G2. Increased that the placental weight and index were significantly higher $(\mathrm{p}<0.05)$ in G3 and G4 compared to the control groups (G1 and G2).

There was an increase in the proportion of SPA foetuses in the diabetic group and diabetic group treated with quercetin in relation to G1 and G2 groups (Table 3).

\section{Discussion}

In our study, the diabetic rats (G3) showed a significant increase in blood glucose levels compared with the control rats. The hypoglycaemic effect of quercetin may be due to its antioxidant properties $[21,22]$.

An assessment of the weight of a pregnant woman is an indirect measurement of the degree of maternal and foetal impairment. Weight gain can lead to insufficient intrauterine growth $[23,24]$. In contrast, in pregnancies complicated by diabetes, maternal weight is often exaggerated, associated with macrosomia and polyhydramnios $[25,26]$. In rats with diabetes induced by drugs, and macrosomia, the excessive maternal weight gain is not easily reproducible. The difference in weight of the foetuses at day 20 , the developmental phase of the foetuses [27,28].

Another explanation is that these disorders may be associated with hyperglycemia in the intrauterine environment [25]. Moreover, it was demonstrated that diabetes leads to thickening of the membranes and limiting the intervillous space [26], with consequent reduction in blood flow and maternal-foetal exchange, thus the flow of blood to the placenta in diabetic rats is reduced by $50 \%$ in late pregnancy [18], restricting the levels of oxygen and nutrients to the foetus, which can cause lower birth weight.

Experimental studies suggest that maternal hyperglycaemia results

\begin{tabular}{|c|c|c|c|c|}
\hline & G1 & G2 & G3 & G4 \\
\hline Foetuses weight $(\mathrm{g})$ & $4,16 \pm 1,0 \mathrm{~b}$ & $4,44 \pm 0,56 \mathrm{~b}$ & $2,29 \pm 0,56 \mathrm{a}$ & $2,87 \pm 0,50 \mathrm{a}$ \\
\hline Placental weight $(\mathrm{g})$ & $0,46 \pm 0,05 \mathrm{a}$ & $0,41 \pm 0,08 \mathrm{a}$ & $0,64 \pm 0,07 \mathrm{c}$ & $0,51 \pm 0,08 \mathrm{~b}$ \\
\hline Placental index & $0,10 \pm 0,01 \mathrm{a}$ & $0,09 \pm 0,01 \mathrm{a}$ & $0,16 \pm 0,05 \mathrm{~b}$ & $0,14 \pm 0,04 \mathrm{~b}$ \\
\hline
\end{tabular}

Mean \pm SD. All data were statistically analysed using analysis of variance (ANOVA) followed by the Tukey test. Means followed by different letters indicate significant differences between the groups $(p<0.05)$. $G 1=$ non-diabetic, $G 2=$ non-diabetic treated with quercetin, G3= diabetic and G4= diabetic treated with quercetin

Table 2: Foetal and placental weights and placental index of the different experimental groups.

\begin{tabular}{|c|c|c|c|c|}
\hline & $\mathrm{G} 1(\mathrm{n}=89)$ & $\mathrm{G} 2(\mathrm{n}=93)$ & $\mathrm{G} 3(\mathrm{n}=71)$ & $\mathrm{G} 4(\mathrm{n}=79)$ \\
\hline SPA (\%) & $1,1 \mathrm{a}$ & $0 \mathrm{a}$ & $35,7 \mathrm{~b}$ & $34,2 \mathrm{~b}$ \\
\hline APA (\%) & $98,9 \mathrm{~b}$ & $97,9 \mathrm{a}$ & $64,3 \mathrm{~b}$ & $65,8 \mathrm{~b}$ \\
\hline LPA (\%) & $0 \mathrm{a}$ & $2,1 \mathrm{a}$ & $0 \mathrm{a}$ & $0 \mathrm{a}$ \\
\hline
\end{tabular}

Porcentage followed by different letters indicate significant differences between the groups $(p<0.05)$. $G 1=$ non-diabetic, $G 2=$ non-diabetic treated with quercetin, $G 3=$ diabetic and $\mathrm{G} 4=$ diabetic treated with quercetin.

Table 3: Percentage of foetuses classified as appropriate for pregnancy age (APA), small for pregnancy age (SPA), and large for pregnancy age (LPA) in the different experimental groups. in a severe renal overload, with the elimination of large amounts of water and electrolytes, dehydration and culminating with the consequent loss or difficulty in gaining weight $[29,30]$. Persistence of a severe hyperglycaemic state in the intrauterine environment prevents the foetal pancreas from obtaining an adequate energy intake from glucose, and restricts development of the foetus between the $18^{\text {th }}$ and $21^{\text {st }}$ days of pegnancy [14]. This situation was confirmed in this study and treatment with quercetin failed to match the weight gain values of the control group, although the weight of these rats did increase significantly $(\mathrm{p}<0.05)$ compared to the diabetic group.

Miscarriages are frequent in women with uncontrolled diabetes [19]. In the diabetic rats, there was a similar outcome, with higher numbers of resorptions and increased rates of post-implantation loss, leading to decreased numbers of live foetuses. The average weight of foetus was lower in the G3 and G4 groups compared to the control group, and the average weight of the placenta in G4 was improved in relation to G3. Treatment with quercetin in the diabetic animals failed to prevent the development of these complications and parameters.

Placental changes have been demonstrated in diabetic women, including the predominance of endarteritis, the thickening of membranes and restriction of the intervillous space (EIV) [19,28], with a consequent reduction in blood circulation and maternal-foetal exchanges. Total blood flow to the placenta in diabetic rats is decreased by $50 \%$ in the last days of pregnancy [31], restricting levels of oxygen and nourishment in the foetus. The increase in placental weight is a compensation mechanism that attempts to increase the surface area for maternal-foetal exchange. However, this increase in placental weight has been shown to be insufficient, hindering foetal nutrition [19]. The high value of the placental index in the diabetic group confirmed placental alteration. As a result, there was a higher proportion of small for gestational age foetuses in the diabetic groups, thus further confirming the existence of placental alteration in maternal-placentalfoetal exchanges [32,33].

Findings in placental morphometry may also have helped to explain the increased rate of intrauterine growth in restriction foetuses of women diabetic and diabetic treated (characterized by a higher classified as small for age of pregnancy).

Although quercetin have improve glucose concentration was not able to improve reproductive and placental development, a fact that might explain what would be the main stimulus for change in these factors seems to be hyperglycaemia, present in the intrauterine environment in the first week of pregnancy, favouring the possible development of oxidative stress, with adverse conditions for the implementation and foetal development, so quercetin may have had its beneficial effect during pregnancy in reducing blood glucose and may not have reduced glucose in the first week, which can have favoured this way the conditions adverse reproductive and placental development.

\section{Conclusion}

Quercetin administered to pregnant diabetic rats controlled glucose levels and promoted weight gain compared to untreated diabetic rats, but it did not improve reproductive performance or foetal or placental development.

\section{Acknowledgements}

This research study was supported by Fundunesp (Fundação para o Desenvolvimento da UNESP Desenvolvimento e Tecnologia Unidade de Informática) and CAPES (Coordenação de Aperfeiçoamento de Pessoal de Nível Superior) 
Citation: Braga CP, de Fátima Ferreira Baptista R, Peixoto FB, Momentti AC, Fava FH, et al. (2012) Effects of Quercetin Administration on the Pregnancy Outcome of Diabetic Rats. J Diabetes Metab 3:180. doi:10.4172/2155-6156.1000180

\section{References}

1. de Souza Mda S, Lima PH, Sinzato YK, Rudge MV, Pereira OC, et al. (2009) Effects of cigarette smoke exposure on pregnancy outcome and offspring of diabetic rats. Reprod BioMed Online 18: 562-567.

2. Amaral S, Oliveira PJ, Ramalho-Santos J (2008) Diabetes and the impairment of reproductive function: possible role of mitochondria and reactive oxygen species. Curr Diabetes Rev 4: 46-54.

3. Coskun O, Kanter M, Korkmaz A, Oter S (2005) Quercetin, a flavonoid antioxidant, prevents and protects streptozotocin-induced oxidative stress and beta-cell damage in rat pancreas. Pharmacol Res 51: 117-123.

4. Szkudelski T (2001) The mechanism of alloxan and streptozotocin action in B-cells of the rat pancreas. Physiol Res 50: 536-546.

5. Shukla N, Rossoni G, Hotston M, Sparatore A, Del Soldato P, et al. (2009) Effect of hydrogen sulphide-donating sildenafil (ACS6) on erectile function and oxidative stress in rabbit isolated corpus cavernosum and in hypertensive rats. BJU Int 103: 1522-1529.

6. Szkudelski T (2001) The mechanism of alloxan and streptozotocin action in B-cells of the rat pancreas. Physiol Res 50: 536-546.

7. Bors W, Heller W, Michel C, Saran M (1990) Flavonoids as antioxidants: determination of radical-scavenging efficiencies. Methods Enzymol 186: 343355.

8. Inal ME, Akgun A, Kahraman A (2002) Radioprotective effects of exogenous glutathione against whole-body gamma-ray irradiation: age and gender-related changes in malondialdehyde levels, superoxide dismutase and catalase activities in rat liver. Methods Find Exp Clin Pharmacol 24: 209-212.

9. Laughton MJ, Evans PJ, Moroney MA, Hoult JR, Halliwell B (1991) Inhibition of mammalian 5-lipoxygenase and cyclo-oxygenase by flavonoids and phenolic dietary additives. Relationship to antioxidant activity and to iron ion-reducing ability. Biochem Pharmacol 42: 1673-1681.

10. Afanas'ev IB, Dorozhko Al, Brodskii AV, Kostyuk VA, Potapovitch Al (1989) Chelating and free radical scavenging mechanisms of inhibitory action of rutin and quercetin in lipid peroxidation. Biochem Pharmacol 38: 1763-1769.

11. Morand C, Crespy V, Manach C, Besson C, Demigné C, et al. (1998) Plasma metabolites of quercetin and their antioxidant properties. Am J Physiol 275 R212-R219.

12. Bhattaram VA, Graefe U, Kohlert C, Veit M, Derendorf H (2002) Pharmacokinetics and bioavailability of herbal medicinal products. Phytomed 9. $1-33$

13. Eriksson UJ, Cederberg J, Wentzel P (2003) Congenital malformations in offspring of diabetic mothers--animal and human studies. Rev Endocr Metab Disord 4: 79-93.

14. Yang J, Cummings EA, O'connell C, Jangaard K (2006) Fetal and neonata outcomes of diabetic pregnancies. Obstet Gynecol 108: 644-650.

15. Calderon IMP, Rudge MVC, Brasil MAM (1992) Diabetes e gravidez experimental em ratas I. Indução do diabete, obtenção e evolução da prenhez. Cirulação Brasileira 7: 9-14.

16. Marcondes FK, Bianchi FJ, Tanno AP (2002) Determination of the estrous cycle phases of rats: some helpful considerations. Braz J Biol 62: 609-614.
17. Fernandes AA, Novelli EL, Okoshi K, Okoshi MP, Di Muzio BP, et al. (2010) Influence of rutin treatment on biochemical alterations in experimental diabetes. Biomed Pharmacother 64: 214-219.

18. Damasceno DC, Kempinas WG, Volpato GT (2008) Anomalias Congênitas: Estudos Experimentais. (First edition) Coopmed, Belo Horizonte.

19. Saito FH, Damasceno DC, Kempinas WG, Morceli G, Sinzato YK, et al. (2010) Repercussions of mild diabetes on pregnancy in wistar rats and on the fetal development. Diabetol Metab Syndr 2: 26.

20. Zar JH (1996) Bioestatistical analysis. (4 ${ }^{\text {th }}$ edition) New Jersey: Prentice Hall 929

21. Sanders RA, Rauscher FM, Watkins JB (2001) Effects of quercetin on antioxidant defense in streptozotocin-induced diabetic rats. J Biochem Mo Toxicol 15: 143-149.

22. Mahesh T, Menon VP (2004) Quercetin Allievates Oxidative Stress in Streptozotocin-induced diabetic rats. Phytother Res 18: 123-127.

23. Damasceno DC, Volpato GT, Calderon Ide M, Aguilar R, Rudge MV (2004) Effect of Bauhinia forficata extract in diabetic pregnant rats: maternal repercussions. Phytomedicine 11: 196-201.

24. Calderon IM, Damasceno DC, Amorin RL, Costa RA, Brasil MA, et al (2007) Morphometric study of placental villi and vessels in women with mild hyperglycemia or gestational or overt diabetes. Diabetes Res Clin Prac 78: 65-71.

25. Calderon IMP (1994) Influência do binômio diabete e gravidez na atividade endócrina do pâncreas materno e fetal - Estudo experimental em ratas. Botucatu: UNESP, 1994. 175f. Tese (Doutorado) - Universidade Estadual Paulista, Botucatu.

26. Reece EA, Coustan DR (1995) Diabetes Mellitus in Pregnancy. Churchil Livingstone, New York

27. Calderon IMP (1988) Modelo experimental em ratas para estudo do binômio diabete e gravidez (dissertação). Botucatu: UNESP, 1988. 195f. Tese (Doutorado) - Universidade Estadual Paulista, Botucatu.

28. Zhao Z, Reece EA (2005) Experimental mechanisms of diabetic embryopathy and strategies for developing therapeutic interventions. J Soc Gynecol Investig 12: $549-557$

29. Davis SN, Granner DK (2006) Insulina, fármacos hipoglicemiantes orais a farmacologia do pâncreas endócrino, In: Goodman \& Gilman: As bases farmacológicas da terapêutica. McGraw-Hill Interamericana 1103-1125.

30. Gangog WF (1991) Endocrine functions of the pancreas and the regulation of carbohydrate metabolism In: Review of medical physiology. Appleton \& Lange, San Francisco, USA 312-333.

31. Del Nero U, Rudge MVC, Calderon IMP (2000) Mecanismos de adaptação placentária facilitadores da nutrição fetal. Femina 28: 91-93.

32. Damasceno DC, Volpato GT, de Mattos Paranhos Calderon I, Cunha Rudge MV (2002) Oxidative stress and diabetes in pregnant rats. Anim Reprod Sci 72: $235-244$

33. Volpato GT, Damasceno DC, Sinzato S (2005) Avaliação do efeito do extrato aquoso das folhas de Morus nigra (Amora) no binômio diabete e gravidez. Diabetes Clín 25: 340-345. 